\title{
Hubungan antara Social Support dan Self-Efficacy dengan Stress pada Ibu Rumah Tangga yang Berpendidikan Tinggi
}

\author{
Syarifah Mustika Sari, Yuliana Intan Lestari, Alma Yulianti \\ UIN Sultan Syarif Kasim, Jl. Subrantas KM 15 Pekanbaru Riau \\ e-mail: alma.yulianti@uin-suska.ac.id
}

\begin{abstract}
This research aims to study about relationship between social support, self-efficacy and stress among housewives who have high education. Daily routine can lead stress on housewives. Social cognitive factors like social support and self-efficacy effect stress experience. Samples are 200 high educated housewives who don't have a job. This research is having incidental sampling technique and using some scales for collecting data such as social support scale, self-efficacy scale, and stress scale. Data were analyzed using Multiple Regression Analysis. The results showed that there is a significant correlation between social support, self-efficacy and stress among high educated housewives with $F=2.197$ and 0.00 significance $(p<0.01)$. It means that the hypothesis proposed by the researchers that there is a correlation between social support, self-efficacy and stress are accepted.
\end{abstract}

Keywords: social support, self efficacy, stress

\begin{abstract}
Abstrak
Penelitian ini bertujuan untuk mengkaji hubungan antara social support dan self efficacy dengan stress pada ibu rumah tangga yang berpendidikan tinggi. Aktivitas monoton dan kompleks yang berlangsung terus-menerus dapat memicu stress. Beberapa faktor sosialkognitif yang dapat mempengaruhi pengalaman stress adalah social support dan self efficacy. Sampel penelitian adalah ibu rumah tangga yang berpendidikan tinggi dan tidak bekerja sebanyak 200 orang yang didapat dengan menggunakan teknik Incidental Sampling. Data penelitian diperoleh menggunakan skala social support, skala self-efficacy, dan skala stress kemudian data dianalisis dengan analisis regresi ganda. Hasil penelitian menunjukkan bahwa terdapat hubungan yang signifikan antara social support dan self efficacy dengan stress pada ibu rumah tangga yang berpendidikan tinggi dengan $\mathrm{F}=2,197$ dan signifikansi $0,00(\mathrm{p}<0,01)$. Hal ini berarti hipotesis yang diajukan oleh peneliti diterima yaitu terdapat hubungan antara social support dan self efficacy dengan stress pada ibu rumah tangga yang berpendidikan tinggi.
\end{abstract}

Kata Kunci: social support, self efficacy, stress

\section{Pendahuluan}

Ibu rumah tangga adalah suatu peran yang otomatis diterima oleh seorang wanita saat mulai berkeluarga. Sebagian waktunya berada di dalam rumah yang memiliki tanggung jawab yang timbul secara spontan dan tidak dapat diramalkan (Kartono, 2006). Ketika wanita memilih untuk menjadi ibu rumah tangga, banyak orang beranggapan bahwa wanita tidak perlu bersekolah jika pada akhirnya setelah menikah tidak bekerja. Selain itu, jika seorang wanita mempunyai pendidikan, lantas setelah menikah memutuskan untuk menjadi ibu rumah tangga, dalam pandangan banyak orang pendidikannya menjadi sia-sia serta rugi dalam membiayai pendidikan itu (Verudyana, 2013).

Menurut UU. No. 12 Tahun 2012 tentang pendidikan tinggi pada pasal 1 ayat (1) menyebutkan bahwa pendidikan tinggi merupakan jenjang pendidikan setelah pendidikan menengah yang men-cakup program diploma, program sarjana, program magister, program doktor dan program profesi serta program spesialis yang diselenggarakan oleh perguruan 
tinggi. Ibu rumah tangga yang berpendidikan tinggi tentunya memiliki keinginan ataupun cita-cita sebagai seorang individu. Merujuk pada pandangan psikologi humanistik yang menekankan "nilai positif" manusia, perempuan juga membutuhkan aktualisasi diri yang optimal demi pengembangan diri (Andani, 1998).

Selain itu, ibu rumah tangga juga dituntut untuk mengerjakan berbagai macam pekerjaan rumah tangga yang dalam setiap harinya dengan jam kerja yang tidak terbatas karena berlangsung terusmenerus. Hal tersebut dianggap mudah bagi sebagian orang, tetapi bagi sebagian lagi pekerjaan rumah tangga merupakan hal yang cukup membebani (Putri \& Sudhana, 2013). Menurut Smet (1994) tuntutan kerja yang terlalu banyak dan beban kerja yang berat dapat menimbulkan stress. Menurut Lazarus (Lubis, 2009) stress merupakan bentuk interaksi antara individu dengan lingkungan, yang dinilai individu sebagai sesuatu yang membebani atau melapaui kemampuan yang dimilikinya, serta mengancam kesejahteraannya. Dengan kata lain, stress merupakan fenomena individual dan menunjukkan respon individu terhadap tuntutan lingkungan

Sebuah penelitian yang dilakukan oleh National Institude for Child Health and Human Development Study of Early Child Care and Youth Development yang melibatkan 1300 perempuan menunjukkan bahwa perempuan yang bekerja di luar rumah walau hanya bekerja part-time memiliki kesehatan yang lebih baik dan lebih sedikit mengalami gejala stress dibandingkan dengan perempuan yang mencurahkan waktunya untuk mengurusi rumah dan keluarga.

Stress yang dialami individu, bukan hanya menyangkut segi fisik saja tapi juga psikologis individu karena manusia adalah mahluk holistik yang merupakan satu kesatuan antara jiwa dan raga, antara roh dan tubuhnya, antara spiritual dan materialnya. Jika individu mengalami stress maka akan berdampak pada segala yang ada diri individu tersebut. Lebih lanjut lagi Hardjana (1994) membagi gejala stress pada wanita ke dalam beberapa jenis, yaitu (1) fisik, berupa sakit kepala, pusing tidur tidak teratur, imsomnia, tekanan darah tinggi, serangan jantung, keringat berlebihan, dan cepat lelah, (2) emosional, berupa gelisah atau cemas, sedih, depresi, mudah menangis mood berubah-ubah, mudah marah, gugup , merasa tidak aman, terlalu peka, mudah tersinggung, (3) intelektual, berupa sulit berkonsentrasi, sulit membuat keputusan, mudah lupa, pikiran kacau, daya ingat menurun, melamun secara berlebihan, pikiran dipenuhi satu pikiran saja, kehilangan rasa humor yang sehat, produktifitas menurun, mutu kerja rendah, dan banyaknya kesalahan yang dibuat suatu tugas (4) interpersonal, berupa kehilangan kepercayaan pada orang lain, mudah mempersalahkan orang lain, mudah membatalkan janji atau tidak memenuhinya, suka mencari-cari kesalahan oranglain, menyerang orang lain dengan kata, mengambil sikap terlalu membentengi, dan mempertahakan diri serta mendiamkan orang lain. Hal ini disebabkan karena seorang ibu rumah tangga harus terisolasi dari lingkungan di luar rumah ketika melakukan pekerjaan rumah tangganya. Melakukan kegiatan yang monoton yang dilakukan di dalam rumah sehari-hari dalam waktu yang berkepanjangan dapat meningkatkan resiko terjadinya stress dan dapat mem-pengaruhi fungsi yang baik sebagai ibu rumah tangga (dalam Putri \& Suhada, 2013).

Menurut Smet (1994) beberapa faktor sosial-kognitif yang dapat mem-pengaruhi serta mengubah pengalaman stress yakni dukungan sosial (social support) yang dirasakan dan self-efficacy. Social support atau yang biasa disebut dengan dukungan sosial adalah tersedianya orang lain atau kelompok yang mem-berikan rasa nyaman, perhatian dan penghargaan ataupun menawarkan bantuan terhadap individu. Dukungan ini berasal dari berbagai sumber, 
yaitu pasangan (suami), keluarga, teman, tetangga dan lain sebagainya (Sarafino, 1994). Dengan adanya rasa nyaman dan perhatian maupun bantuan dari berbagai sumber social support akan meningkatkan keyakinan ibu rumah tangga yang mampu mengerjakan tugas-tugas rumah tangga dengan baik.

Keyakinan atau self-efficacy yakni kepercayaan individu mengenai kemampuan dirinya untuk mengorganisasi, dan melakukan suatu tugas dalam mencapai tujuan, menghasilkan sesuatu dan mengimplementasi tindakan untuk menampilkan kecakapan tertentu (Bandura dalam Santrock, 2007). Self-efficacy yang tinggi membantu individu untuk menyelesaikan tugas dan mengurangi beban secara psikologis maupun fisik sehingga stress yang dirasakan pun kecil (Mariza, dkk: 2006).

Kurangnya dukungan dari keluarga ditambah dengan tidak adanya keyakinan bahwa ia mampu mengerjakan tugas sebagai ibu rumah tangga disertai masalahmasalah yang muncul dalam menjalani hidup, bagi ibu rumah tangga yang memiliki latar belakang pendidikan tinggi tentunya hal ini dapat menimbulkan tekanan, sehingga dalam dirinya tidak akan mendapatkan kepuasan dalam kehidupan sehari-hari. Berdasarkan uraian diatas peneliti tertarik untuk meneliti tentang hubungan antara social support dan selfefficacy dengan stress pada ibu rumah tangga yang berpendidikan tinggi.

\section{Metode Penelitian}

\section{Subjek Penelitian}

Subjek dalam penelitian berjumlah 200 orang yang merupakan ibu rumah tangga berpendidikan tinggi di Kecamatan Tampan, Pekanbaru.. Teknik pengambilan sampel yang digunakan adalah teknik incidental sampling. Teknik ini merupakan penentuan sampel berdasarkan kebetulan, artinya siapa saja yang secara kebetulan bertemu dengan peneliti dapat digunakan sebagai sampel, bila dipandang orang yang kebetulan ditemui itu cocok sebagai sumber data (Sugiyono, 2010). Beberapa karakteristik subjek yang hendak diteliti adalah sebagai berikut; (1) Ibu rumah tangga yang hanya mengerjakan pekerjaan rumah tangga. (2) Berusia 20-40 tahun. Menurut Hurlock (2004) dari awal masa dewasa dini, individu disibukkan dengan masalah-masalah yang berhubungan dengan penyesuaian diri dari berbagai aspek utama kehidupan orang dewasa seperti kehidupan perkawinan, peran sebagai orangtua, dan karir. (3) Pendidikan minimal diploma, program sarjana, program magister, program doktor dan program profesi serta program spesialis (UU. No. 12 Tahun 2012 pasal 1 ayat (1).

Jumlah subjek yang akan digunakan dalam penelitian ini adalah 200 orang, untuk meminimalisir berbagai hambatan yang mungkin mucul serta dengan mempertimbangkan jumlah po-pulasi tertinggi dari beberapa kecamatan peneliti memilih lokasi yaitu Kecamatan Tampan.

\section{Alat Ukur \\ Pengumpulan data dalam penelitian ini menggunakan skala Likert yang telah dimodifikasi dengan menghilangkan jawaban netral untuk menghindari jawaban subjek ketengah (central tendency effect).Skala stress telah diujicobakan berdasarkan aspek-aspek stress menurut Harjana (1994), skala social support telah diujicobakan berdasarkan aspek-aspek social support menurut Sarafino(1997), dan skala self-efficacy disusun berdasarkan aspek dari Bandura (1997) yang di- tuangkan dalam skala General Self-Efficacy (GSE) oleh Schwarzer \& Jarusalem (1995).}

\section{Analisis Data}

Analisis data penelitian ini menggunakan Analisis Regresi Ganda (Multiple Regretion) yakni teknik statistik yang digunakan untuk menganalisis hubungan antara satu variabel dependen dengan beberapa variabel bebas (Hair dkk, 2006). Analisis dalam penelitian dilakukan 
menggunakan bantuan komputerisasi Statistical Product and Service Solutions (SPSS) 17.0 for Windows.

\section{Hasil Penelitian dan Pembahasan}

\section{Hasil Penelitian}

Berdasarkan hasil uji normalitas yang dilakukan, variabel social support $\left(\mathrm{X}_{1}\right)$ diperoleh rasio skewness sebesar -1,430 dan rasio kurtosis sebesar -1,523, variabel selfefficacy $\left(\mathrm{X}_{2}\right)$ diperoleh rasio skewness sebesar 0,180 dan rasio kurtosis sebesar 0,230, variabel stress (Y) diperoleh rasio skewness sebesar 1,238 dan rasio kurtosis sebesar -0,035. Rasio skewness dan rasio kurtosis ketiga variabel penelitian ini berada dalam rentang anatara -2 sampai 2 , dengan demikian dapat disimpulkan bahwa distribusi data dalam penelitian ini adalah normal.

Hasil uji linieritas yang dilakukan terhadap variabel social support*stres sdiperoleh nilai $\mathrm{F}=101.657$ dengan signifikansi sebesar 0,00 dan varibel selfefficacy*stress diperoleh hasil $\mathrm{F}=$ 26.954 dengan signifikansi sebesar 0,00 . Berdasarkan hasil tersebut dapat disimpulkan bahwa data dari ketiga variabel menunjukkan hubungan liner yakni memperoleh nilai signifikansi lebih kecil dari 0,05.

Berdasarkan hasil Analisis Regresi Ganda (Multiple Regression) menunjukkan $\mathrm{F}(2,197)=59,255$ dan diperoleh nilai signifikasi sebesar 0,00. Hal menunjukkan bahwa hipotesis yang diajukan oleh peneliti diterima yakni ada hubungan antara social support dan self-efficacy dengan stress pada ibu rumah tangga yang berpendidikan tinggi. Selanjutnya, hasil kontribusi tiap variabel menunjukkan nilai signifikansi variabel social support sebesar 0,00 dengan nilai koefisien sebesar $-0,646$ dan nilai signifikansi variabel self-efficacy sebesar 0,004 dengan nilai koefisien sebesar -0,641. Hal ini menunjukkan bahwa hubungan antarasocial support dan self-efficacy dengan stress pada ibu rumah tangga yang berpendidikan tinggi di Kecamatan Tampan berkorelasi negatif.Artinya, semakin tinggi social support dan self-efficacy maka semakin rendah stress yang dialami oleh ibu rumah tangga yang berpendidikan tinggi, begitu juga sebaliknya.

Selanjutnya, diperoleh nilai adjusted $\mathrm{R}^{2}$ sebesar $36,9 \%$, artinya stress mampu

Tabel 1

ANOVA $^{b}$

\begin{tabular}{|c|c|c|c|c|c|c|}
\hline Model & & $\begin{array}{l}\text { Sum } \\
\text { Squares }\end{array}$ & Df & Mean Square & $\mathrm{F}$ & Sig. \\
\hline \multirow[t]{3}{*}{1} & Regression & 13461.258 & 2 & 6730.629 & 59.255 & $.000^{\mathrm{a}}$ \\
\hline & Residual & 22376.562 & 197 & 113.587 & & \\
\hline & Total & 35837.820 & 199 & & & \\
\hline
\end{tabular}

a. Predictors: (Constant), SelfEfficacy, SocialSupport

b. Dependent Variable: Stress

Tabel 2

Coefficients ${ }^{\mathrm{a}}$

\begin{tabular}{|c|c|c|c|c|c|c|}
\hline & \multirow[b]{2}{*}{ Model } & \multicolumn{2}{|c|}{$\begin{array}{c}\text { Unstandardized } \\
\text { Coefficients }\end{array}$} & \multirow{2}{*}{$\begin{array}{c}\text { Standardized } \\
\text { Coefficients } \\
\text { Beta }\end{array}$} & \multirow[b]{2}{*}{$\mathrm{t}$} & \multirow[b]{2}{*}{ Sig. } \\
\hline & & B & Std. Error & & & \\
\hline \multirow[t]{3}{*}{1} & (Constant) & 146.916 & 7.626 & & 19.266 & .000 \\
\hline & SocialSupport & -.646 & .072 & -.535 & -9.016 & .000 \\
\hline & SelfEfficacy & -.641 & .219 & -.174 & -2.928 & .004 \\
\hline
\end{tabular}

a. Dependent Variable: Stress 
dijelaskan dengan social support dan selfefficacy sebesar $36,9 \%$ sedangkan $63,1 \%$ dapat dipengaruhi oleh faktor lain seperti faktor sosial-kognitif lainya (atribusi dan kontrol), karakteristik kepribadian, kondisi individu (usia, suku, kebudayaan, kondisi fisik) dan lain sebagainya (Smet, 1994).

\section{Pembahasan}

Berdasarkan hasil analisis dengan menggunakan bantuan Statistical Product and Service Solutions (SPSS) 17.0 for Windows menunjukan bahwa terdapat hubungan yang signifikan antara social support dan self-efficacy dengan stress pada ibu rumah tangga yang berpendidikan tinggi di Kecamatan Tampan. Sebagaimana yang diungkapkan oleh Sarason dkk (dalam Baron dan Byrne, 2005) bahwa social support dalam hal kenyamanan secara fisik dan psikologi yang diberikan orang lain adalah hal yang bermanfaat ketika diri mengalami stress. Hal ini juga diperkuat oleh hasil penelitian James LaRocco, James House dan John French (dalam Sarafino, 1997) yang menunjukkan bahwa social support dapat mengurangi pengalaman stress yang dialami seseorang. Ketika ibu rumah tangga yang berpendidikan tinggi merasa tertekan dengan peran serta tanggung jawabnya sebagai ibu rumah tangga, berhubungan dengan orang lain yang merupakan sumber rasa nyaman dapat membantu mengurangi tekanan yang dihadapi oleh ibu rumah tangga yang berpendidikan tinggi.

Konsep dari social support menunjukan bahwa ada pihak yang memberikan perhatian pada individu yang sedang berada dalam suatu keadaan stress. Keluarga merupakan salah satunya, peran dari keluarga dalam memberikan social support kepada ibu rumah tangga yang berpendidikan tinggi sangat penting, hal ini sesuai dengan pendapat dari Jim Siegel

(dalam Taylor, 1999) yang mengatakan bahwa social support merupakan suatu informasi dari orang lain dimana seseorang yang dicintai, diperhatikan, dihargai, dan dinilai tinggi serta adanya jaringan komunikasi dari pihak orang tua, suami, atau, kerabat.

Maka, dapat dikatakan bahwa ketika ibu rumah tangga yang ber-pendidikan tinggi mendapat social support yang dimanifestasikan dalam bentuk perhatian, perasaan yang dihargai, dan dihormati, ibu rumah tangga yang berpendidikan tinggi yang kesehariannya berkewajiban mengurus rumah tangga dapat mengatasi stress dalam menghadapi persoalan rumah tangga. Hal ini juga sejalan dengan pendapat Bart Smet (1994) yang mengatakan bahwa faktor-faktor yang dapat mengubah pengalaman stress antara lain adanya hubungan dengan lingkungan sosial, social support yang diterima, serta intergrasi dalam jaringan sosial.

Selain itu, menurut Smet terdapat faktor sosial-kognitif lain seperti selfefficacy juga sangat mempengaruhi stress. Hal ini sejalan dengan pendapat Bandura (dalam Smet, 1994) yang menyatakan bahwa self-efficacy dapat mempengaruhi setiap tingkat perubahan pribadi serta kebiasaan yang berkaitan dengan kesehatan yakni dapat meningkatkan ke-kebalan terhadap stress. Self-efficacy merupakan persepsi diri mengenai seberapa baik diri dapat berfungsi dalam situasi tertentu. Dengan mengetahui sejauh mana kemampuan diri yang dimiliki maka seorang ibu rumah tangga yang berpendidikan tinggi mampu melakukan tindakan yang maksimal dalam mencapai sebuah tujuan yang telah ditetapkan sebelumnya.

Tingginya tingkat keperdulian dan perhatian yang didapatkan dari keluarga, teman dan lingkungan diiringi dengan keyakinan diriyang tinggi membuat ibu rumah tangga yang berpendidikan tinggi di Kecamatan Tampan mampu mengatasi berbagai tuntutan dan situasi dalam berumah tangga sehingga stress yang dialami cenderung rendah.

Menurut penelitian yang dilakukan oleh National Institude for Child Health 
and Human Development Study of Early Child Care and Youth Development menunjukkan hasil bahwa perempuan yang bekerja di luar rumah walau hanya bekerja part-time memiliki kesehatan yang lebih baik dan lebih sedikit mengalami gejala stress dibandingkan dengan perempuan yang mencurahkan waktunya untuk mengurusi rumah dan keluarga. Meskipun demikian, penelitian ini menunjukkan hasil yang berbeda yakni berdasarkan hasil analisis data, stress pada ibu rumah tangga yang berpendidikan tinggi di kecamatan Tampan memiliki kecenderungan tingkat stress yang rendah.

Ketika seorang ibu rumah tangga berpendidikan tinggi, kemudian menikah dan memilih menjadi ibu rumah tangga. Hal itu bukan berarti tidak bekerja dan pendidikan yang telah diperoleh menjadi sia-sia, tetap wanita adalah seorang ibu rumah tangga dan apapun itu bidang ilmu yang digeluti selama masa pendidikan akan sangat berguna serta bermanfaat dalam kehidupan sehari-hari dalam berumahtangga (Verudyana, 2013). Se-jalan dengan pendapat ini, Putri (2013) mengatakan bahwa meskihanya sebagai ibu rumah tangga yang pernah menempuh pendidikan, dan memperoleh ilmu atau pengetahuan hingga memiliki gelar sar-jana, dapat dimanfaatkan oleh ibu-ibu rumah tangga yang berpendidikan tinggi untuk mendidik anak. Selain itu, pen-didikan juga dapat membantu seseorang dalam bergaul, baik itu cara bersikap, cara menghadapi orang, serta cara berbicara.

Dengan demikian, adanya social support yang diterima oleh ibu rumah tangga dari berbagai pihak terutama keluarga serta tingginya self-efficacy yakni keyakinan bahwa ia mampu mengurus anak dan suami serta mengerjakan berbagai pekerjaan dan menghadapi masalah yang muncul dalam be-rumahtangga, membuat ibu rumah tangga yang berpendidikan tinggi di Kecamatan Tampan mampu mengatasi stress yang muncul di dalam kehidupan sehari-hari.

\section{Simpulan}

Berdasarkan hasil analisis penelitian yang telah dilakuakan dapat disimpulkan bahwa adahubungan negatif antara social support dan self efiicacy dengan stress pada ibu rumah tangga yang berpendidikan tinggi di Kecamatan Tampan, artinya semakin tinggi social support dan selfefficacymaka semakin rendah stress yang dialami oleh ibu rumah tangga yang berpendidikan tinggi, begitu pula sebaliknya.

\section{Daftar Pustaka}

Andani, K. W. (1998). Dilemma antara perempuan berkarier dan sebagai ibu rumah tangga. Jurnal Humaniora, 8, 20-26.

Azwar, S. (2012). Penyusunan skala psikologi (edisi ke-2). Yogyakarta: Pustaka Pelajar.

Bandura, A. (1997). Self-efficacy the exercise of control. New York: W.H. Freeman and Company.

Baron \& Byrne. (1990). Psikologi kesehatan. Jakarta: PT.Gramedia Widiasarana Indonesia.

Bart, S. (1994). Psikologi kesehatan. Jakarta: PT Grasindo.

Brecht, G. (2000). Mengenal dan mengulas stres.

Hardjana, A. (1994). Stres tanpa distres: Seni mengolah stres. Yogyakarta: Kanisius.

Hawari, D. (2007). Al-Quran: Ilmu kedokteran jiwa \& kesehatan jiwa. Jakarta: PT. Dana Bakti Prima Yasa.

Hurlock, E. B. (2004). Psikologi perkembangan: suatu pendekatan rentang kehidupan (edisi ke-5). Jakarta: Erlangga.

Kartono, K. (2006). Psikologi wanita: Gadis remaja dan wanita dewasa (jilid 1). Bandung: Alumni Penerbit.

Lubis, N. L., (2009). Depresi tinjauan psikologis. Jakarta: Kencana. 
Putri, K. A. K., \& Sudhana, H. (2013). Perbedaan tingkat stres pada ibu rumah tangga yang menggunakan dan tidak menggunakan pembantu rumah tangga. Jurnal Psikologi Udayana, 1(1) 94-105.

Santrok, J. W. (2012). Life span development: Perkembangan masahidup (edisi ke-13, jilid 2). Jakarta: Erlangga.

Sarafino, E. P. (1994). Health Psycology: Biopsycology Interaction (2nd edition). Toronto: Jhon Wiley and Sons. Inc.

Sarafino, E. P. \& Smith, T. W. (2010). Health Psycology: Biopsycology Interaction (7th edition). Toronto: Jhon Wiley and Sons. Inc.
Sarason, I. G., Levine, H. M., Basham, R. B., \& Sarason, B.R. (1983). Assesing social support: the social questionnaire. Journal of Personality and Social Psychology, 4(1), 127-139.

E. T., Letitia, A. P., David, O.S. (2009). Psikologi sosial (edisi ke-12). Jakarta: Kencana Prenada Media Group.

Taylor, S.E. (1999). Health psycology (9th edition). New York: Mc Graw-Hill Inc.

Verudyana, E. P. (2013). Konstruksi Sosial Gelar Sarjana bagi Ibu Rumah Tangga yang Tidak Bekerja Di Sektor Publik. Jurnal Psikologi, 2(2) 
Psympathic, Jurnal Ilmiah Psikologi Desember 2016, Vol. 3, No. 2, Hal: 171 - 178 